This item was submitted to Loughborough's Research Repository by the author.

Items in Figshare are protected by copyright, with all rights reserved, unless otherwise indicated.

\title{
Potential of biodegradable microneedles as a transdermal delivery vehicle
} for lidocaine

PLEASE CITE THE PUBLISHED VERSION

http://dx.doi.org/10.1007/s10529-013-1217-3

PUBLISHER

(c) Springer Science+Business Media

VERSION

AM (Accepted Manuscript)

LICENCE

CC BY-NC-ND 4.0

\section{REPOSITORY RECORD}

Nayak, Atul, and Diganta Bhusan Das. 2014. "Potential of Biodegradable Microneedles as a Transdermal Delivery Vehicle for Lidocaine”. figshare. https://hdl.handle.net/2134/14346. 
This item was submitted to Loughborough's Institutional Repository (https://dspace.lboro.ac.uk/) by the author and is made available under the following Creative Commons Licence conditions.

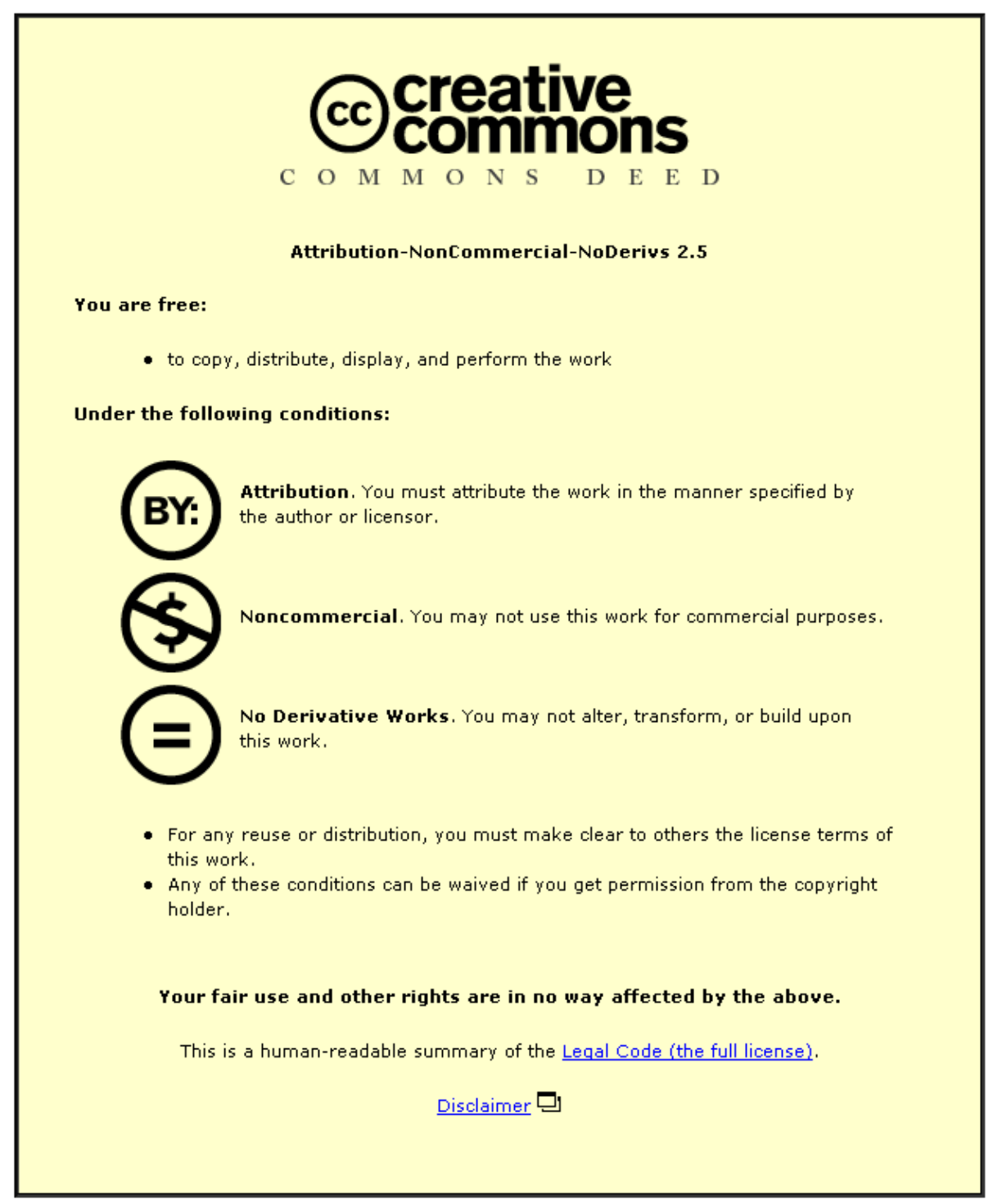

For the full text of this licence, please go to: http://creativecommons.org/licenses/by-nc-nd/2.5/ 


\title{
REVIEW
}

\section{Potential of biodegradable microneedles as a transdermal delivery vehicle for lidocaine}

\author{
Atul Nayak · Diganta Bhusan Das* \\ Department of Chemical Engineering, Loughborough University, Loughborough LE11 3TU, \\ UK
}

*Corresponding author (email: D.B.Das@lboro.ac.uk)

\begin{abstract}
There has been an increasing interest in applying biotechnology in formulating and characterising new and innovative drug delivery methods, e.g., drug-loaded biodegradable microneedles within the area of transdermal delivery technology. Recently, microneedles have been proposed for use in pain management, e.g., post-operative pain management through delivery of a local anaesthetic, namely, lidocaine. Lidocaine is a fairly common, marketed prescription-based local anaesthetic pharmaceutical, applied for relieving localised pain and lidocaine-loaded microneedles have been explored. The purpose of this review is to evaluate the properties of biodegradable polymers that may allow the preparation of microneedle systems, methods of preparing them and pharmacokinetic conditions in considering the potential use of lidocaine for delivery through the skin.
\end{abstract}

Keywords Lidocaine - Biodegradable - Microneedles - Moulds · Substrate - Tensile Strength 


\section{Introduction}

There has been an increasing interest in applying biotechnology in formulating new and innovative drug delivery methods, including biodegradable microneedles within the area of transdermal drug delivery technology (Orive et al. 2003; Olatunji and Das 2010; Olatunji and Das 2011). Conventional hypodermic needle delivery causes pain and anxiety, and requires medical personnel for administration. In contrast, the biodegradable microneedle, a drugloaded vehicle moulded into an all-in-one drug formulated micro-structure constructed from either biopolymer or sugar excipients, can be used to deliver drug almost painlessly to humans (e.g., Donnelly et al. 2010; Lhernould and Delchambre 2011; Olatunji and Das 2011; Gittard et al. 2012). These microneedles are economical due to fairly cheap materials, reproducible and are generally safe if microneedle fragments break off after piercing the skin surface as compared to other microneedles made with glass or metal.

Large molecular weight proteins such as bovine serum albumin (BSA), growth hormones and vaccines have been successfully loaded into biodegradable microneedles (Lee et al. 2008; Lee et al. 2011a; Raphael et al. 2010). Recently, the microneedles have also been explored for use in post-operative pain management through delivery of a local anaesthetic, lidocaine. Lidocaine provides short duration, superficial anaesthesia, to the pain-affected area (Kissin 2012). Lidocaine (Fig. 1a) comprises of a polar tertiary amine and a hydrophobic aromatic group on the opposite ends of the acetamide bond (Costa et al. 2008). It is hydrophobic as the basic drug but it is soluble in water as the ionised form of lidocaine hydrochloride (Fig. 1b) in which the tertiary amine is protonated (Ullah et al. 2012; Rajabi et al. 2011; Shaikh et al. 2011). Therefore, lidocaine can be encapsulated or dispersed in a drug delivery vehicle which could be either hydrophobic or hydrophilic.

Fig. 1 a

Fig. $1 \mathrm{~b}$ 
In the present context, a vehicle for drug delivery is taken as a support material for formulating drugs usually in liquid-based or a semi-solid form to remain on the skin surface and facilitate the conditions necessary for transdermal drug delivery (Allen et al. 2005; Djabri et al. 2012; Subedi et al. 2010). An ideal drug carrier system or vehicle is sought for identifying optimal conditions in controlled release and transdermal permeation kinetics of the drug lidocaine. The main objective of using a vehicle is either to allow for fast initial release or permeation in skin with consideration to the suitability of suturing a superficial cut or a slow initial release and longer steady state conditions lasting several hours with an alternative consideration to suturing and treating multiple lacerations at the localised area.

A formulation of lidocaine has been developed by Fiala et al. (2011) for EMLA (eutectic mixture of local anaesthetics) containing lidocaine and prilocaine in hydrofluoroalkane as a propellant enhancer spray. Kaewprapan et al. (2012) studied lidocaine-loaded nanoparticles of dextran decanoate esters with varying degrees of substitution for suspension in aqueous medium. Petrisor et al. (2012) mixed lidocaine with silicone elastomer and analysed the controlled release effects of modifiers such as poly(vinylpyrrodidone), PVP, and poly(vinyl alcohol), PVA. Compared with injectable and skin- surface drug applicants, microneedles are highly beneficial in terms of constant needle lengths being below the length causing epidermal pain stimulation during insertion (Banga 2009), while respectively described as minimally invasive in forming micro-spaces (Daugimont et al. 2010) in conjunction to enhancing the movement of the active compounds through the skin (Ameri et al. 2010; Chu et al. 2010).

Besides the laboratory-based studies mentioned above, there are a number of proprietary transdermal delivery systems for lidocaine. These include proprietary medicines in solution, semi-solid and patch delivery system. For example, lidocaine in solution is combined with a bacterially-derived hyaluronic acid gel formula to minimise the discomfort of injection as a tissue filler in the cosmetics industry (Monhiet et al. 2009). The proprietary name of the formulation is Prevelle Silk (Mentor Pharmaceuticals, www.mentorcorp.com). Lidocaine solution is marketed under the proprietary name of Xylocaine and is also available in an 
injectable format (www.astrazeneca.co.uk). Clinical research has shown that a $1 \%(w / v)$ lidocaine subcutaneously injected once into the location of a lacerated, injured or tumouraffected hand allows for successful local anaesthesia followed by surgical treatment (Tzeng and Chen, 2012). A lidocaine patch for the application to skin is also marketed with the proprietary name Lidoderm (www.Lidoderm.com). A Lidoderm (5\% w/v) patch has been applied for the treatment of postherpetic neuralgia (Katz et al. 2002) and in the reduction of pain during treatment of Dercum's disease (Desai et al. 2008).

Conceptually, microneedle technology provides an attractive method for delivering lidocaine. For example, it may be possible to apply the drug over a large surface area on the body with no or little pain in contrast to traditional hypodermic injections. With microneedles it may be possible to control the drug delivery rate as well besides reducing wastage of the drug. As far as we know, there is no commercially-based lidocaine microneedle product available from pharmacies. However, there seems to be some developmental research for lidocaine microneedles. Recently, the $3 \mathrm{M}$ group developed a lidocaine solution mixed with Dextran to uniformly coat medical-grade, liquid crystalline polymer (class VI) for pre-clinical in vivo studies using biopsy porcine skin of live pigs resulting in successful delivery of lidocaine at a faster time compared to eutectic mixture of local anaesthetics (EMLA) composed of lidocaine and prilocaine as a combined eutectic formulation (Zhang et al. 2012; Schreiber et al. 2013). A less recent but highly significant development was made by Theraject, Inc (Kwon. 2004) with regards to determining the permeation flux of lidocaine through the skin by testing a Theraject MAT dissolvable microneedle system. This vehicle comprised sodium carboxymethyl cellulose mixed with lidocaine and was cast, compressed and moulded to dryness with a subsequent diffusion characterisation that confirmed the permeation flux had increased up to 12 -fold compared to $10 \%(\mathrm{w} / \mathrm{v})$ lidocaine as control (Kwon 2004). The degree of subsitition, in terms of exchanged hydroxyl groups to carboxymethyl groups in sodium carboxymethyl cellulose, effected solubility, viscosity, gel strength and electro-analytical behaviour as an anionic polymer in solution requires further work in order to aim for a plastic material property (Kundu et al. 2011). 
While the above studies show the potential for applying the principles of biotechnology for preparing lidocaine-loaded microneedles, there is a clear need to make further progress on the methods of preparation and characterisation of the microneedles for drug delivery. It may also be necessary to learn from what have been done elsewhere while loading and delivering other molecules (e.g., insulin) using biodegradable microneedles. To address these issues, this review paper aims to evaluate critically the current developments in biodegradable microneedle systems for possible applicability in transdermal lidocaine delivery. In particular, this paper reviews the methods of preparation and the properties of biodegradable polymers that may allow for the development of a desirable microneedle system for lidocaine delivery. It is expected this would be helpful in preparing biodegradable microneedle for lidocaine delivery.

\section{Preparation of biodegradable microneedles}

The first published paper on microneedles was in 1947 in which soft glass material (30 microns tip diameter and $2.5 \mathrm{~cm}$ long) was an example of early microneedles in assisting the isolation of yeast ascospores (Thaysen and Morris 1947). Gerstel and Place (1976) were the first to obtain a patent for the architecture of microneedle arrays, outlining a drug solution reservoir to a flow-through hollow microneedle. In 1998, a paper on the fabrication of microneedles used silicon-layered chromium for 'coat and poke' delivery of drugs (Henry et al. 1998). The first published fabrication of biodegradable microneedles used micromachining technology to mould polycaprolactone polymer into microneedles (Armani and Chang 2000; Park et al. 2003). At the moment, there is clearly an increasing interest in preparing biodegradable microneedles for a variety of applications.

Preparation and treatment of normal skin surface before the application of a microneedle has not been recommended. Most literature suggests that pathogenic infections are not caused by using microneedles (Arora et al. 2008; Donnelly et al. 2009; Han et al. 2012). The removal of microneedles leaves indents on the skin and the main factors, such as microneedle length, number in an array and microneedle cross-sectional area, effect the 
time for natural skin resealing (Gupta et al. 2011). For example, Kalluri and Banga (2011) have characterised the micro-conduit channels caused by microneedles and pore re-sealing. They show that skin pores close partially in approx. $12 \mathrm{~h}$ and completely in approx. $15 \mathrm{~h}$.

A direct thumb application for biodegradable microneedles allow the drugs encapsulated inside the microneedles to diffuse into the viable epidermis of the skin as outlined schematically in Fig. 2a (Shakeel et al. 2011; Kim et al. 2012a). However in the case of lidocaine, if the drug is concentrated in the middle to lower portion of the microneedle than the tip, the permeation is expected to be in the stratum corneum (SC) layer of the skin to anaesthetise a superficial cut.

Fig. 2 a

As such, one needs to consider where the drug is loaded in the microneedles. Compared with glass and metal microneedles, biodegradable microneedles have no or little safety concern if they break and embed in the skin as a foreign body (Park et al. 2007a). Also, the manufacturing process and reproducibility of biodegradable microneedles are economical compared with conventional micro-machining manufacture (Donnelly et al. 2010). Fig. $2 b$ is an image of sodium carboxymethyl cellulose-biodegradable microneedles encapsulated with the drug sulforhodamine $\mathrm{B}$ and Fig. $2 \mathrm{c}$ is an SEM plan view of PLGA microneedles (Jeong et al. 2008; Park et al. 2007a).

Fig. 2 b

Fig. 2 c

Fabrication of biodegradable microneedles from substrate masters.

Biodegradable microneedles have been fabricated by a variety of means. For example, silicon master substrate is adapted in MEMS applications and less time consuming, mass 
producing techniques were researched via operations from the microelectronics industry, known as microelectronic mechanical systems (MEMS) for the fabrication of a master microneedle array prior to micromoulding (Fujita 1997; Walraven 2003; Trautmann et al. 2005). SU-8, 1-methoxy-2-propyl acetate, (Microchem Corp, MSDS) is a negative photoresist material mixed with a Sulfonium salt photoinitiator for inducing the mechanism of cationic polymerisation in epoxy groups of SU-8 monomers under UV (Zhang et al. 2001; Qvortrup et al. 2011). It is photosensitive to UV light and a special mask diffraction grating is required to direct a particular wavelength onto the SU-8 (Ami et al. 2011). SU-8 does not always provide accurate structures and cases of bending brought by high residual stress were observed when photoresist and substrate posses incompatible thermal expansion coefficients. As such, the UV exposure time and wavelength range need close monitoring to prevent the distorting structure (Safavieh et al. 2010; Del Campo and Greiner 2007). Marasso et al. (2011) implemented double spin coating with two different viscosities of SU-8 and observed good adhesion properties between copper substrate and SU-8 in-conjunction to an aspect ratio of 7:1 without additional steps such as wafer removal and seed layer introduction, extending production period over $24 \mathrm{~h}$. Also, the viscosity and set thickness of the SU-8 photoresist are dependent on the amount of $\mathrm{y}$-butyrolactone solvent dissolved in producing the solution (Lorenz et al. 1997).

A recent starting material for production of master templates was reported by Viero et al. (2012). They used reactive-ion etching (RIE) on silicon based master for the construction of microneedles. Chen et al. (2008) also outlined a fabrication process which used silicon oxide layers on silicon followed by a positive photoresist treatment for pattern transfer onto the silicon oxide layer via RIE and finally producing microneedle tips using an isotropic RIE process. Lhernould and Delchambre (2011) arrived at a design fabrication process of implementing laser ablation to create microchannels in polycarbonate material. Matteucci et al. (2009) adapted the micro-fabrication process known in German as lithographie, galvanoformung, abformung (lithography, electroplating and molding) by Hruby (2001) which produced microneedles by double-exposure, deep X-ray lithography (Kim et al. 2004) using 
microcrystalline silicon wafers surfaced with $\mathrm{Cr} / \mathrm{Au}$ bilayer as a template. Even though complicated multi-step processes and specialist resources are required in the production of a large quantity of master microneedles, the production of a single master is economical and time saving when considering the transferability in creating an inverse micromould for biodegradable microneedles (Kim et al. 2009; Kim et al. 2012b).

\section{Fabrication of biodegradable microneedles from moulds}

Biodegradable microneedles have been manufactured from micromoulds that are noninterconnecting micro-well structures (Ryu et al. 2007). There is a lack of publications which outline the micro-moulding fabrication processes methodically. However, the manufacturing processes of casting and hot embossing are common for biodegradable microneedles, which are discussed briefly. In the casting process, a master template is fabricated to develop a mould template for a molten drug formula to fill the mould contours, solidify via favourable temperature and pressure conditions and finally removal of the mould from the solidified drug formula (Bariya et al. 2011). Poly-dimethyl-siloxane (PDMS) is an ideal material for replica moulding of microneedles because of its non-toxicity, elastic properties and low cost (Saliterman 2006; Lee and Lee 2008) and as such, it has been used in many studies. Laser ablation by focusing a $\mathrm{CO}_{2}$ laser was used to create conical shaped voids in PDMS material moulds for vacuum setting sodium carboxymethylcellulose and polyacrylamide solution into solid microneedles (Kim et al. 2009). In another study, a prefabricated PDMS mould was used to vacuum set PLGA microneedles containing hydrogels (Kim et al. 2012b). PLGA is composed of D,L-polylactic acid (PLA) and polyglycoloic acid (PGA) monomers (Gabor et al. 1999; Danhier et al. 2012). As a biocompatible polymer, PLGA is used in biotechnology for the goal of preparing biodegradable microneedles and scaffolds in tissue engineering (Lee et al. 2004). It has been argued that PLGA with low molecular weights of less than $50 \mathrm{kDa}$ and $\mathrm{D}, \mathrm{L}$-lactide/GA ratio of $50: 50$ are the most suitable for controlled drug release with respect to faster degradation rates (Fredenberg et al. 
2011; Mundargi et al. 2008). PLGA in the context of merchandise is commercially and readily available from many chemical suppliers.

Stages in a typical casting process (Fig. 3a, Chu et al. 2010) start with a PDMS mould (step 1), pre-fabricated from a PDMS male master coated with gold, and the mould is filled with sulforhodamine B (step 2). The residual drug solution is pipette extracted half-way to be reused later (step 3) and the remaining drug solution in the mould crevice is dried by centrifugation. The PVA/PVP blend devoid of drug is casted into the mould by vacuum pressure (step 4), the combined polymer is air dried or low speed centrifuged in drying (step 5) and adhesive backing is used to prise the formed polymer microneedles from the PDMS mould (step 6). Another biodegradable polymer system, poly-lactide-co-glycolide (PLGA) fabricated by Park et al. (2003) (Fig. 3b) commenced with SU-8 substrate (step 1) by using the same PLGA polymer as a sacrificial filler on SU-8 (step 2) followed by copper-coating deposition and acid etching to cover the SU-8 epoxy cylinders as a pattern (step 3) with subsequent reactive ion etching (RIE) to asymmetrically etch the tips of epoxy cylinders (step 4) and an inverse PDMS mould was created (step 5) with the prior master structure from RIE method before casting new PLGA microneedles as the final product (step 6) (Park et al. 2003).

Fig. $3 \mathrm{a}$

Fig. $3 \mathrm{~b}$

A more economical method using a natural clay, chinese purple ceramic mould was formed by hydraulic pressing a bed of steel sticks into the soft pliable clay before furnace heating, slow cooling followed by pouring a mixture of PVA, dextran and carboxymethylcellulose polymers into the mould then vacuum setting, freeze thawing and finally drying into microneedles (Yang et al. 2012).

A less common fabrication technique known as hot embossing requires the application of heat above the glass transition temperature of the polymer product in contact with the mould 
followed by force to emboss the mould pattern to the polymer product and then cooling below the glass transition temperature before separation of mould and polymer product (Bodhale et al. 2009). Poly-L-lactic acid (PLLA) is commercially and readily available from many chemical suppliers, similar to PLGA. PLLA microneedles were fabricated by a hot embossing technique through a multi-step process via a PDMS replication and then heating and pressuring the PDMS mould and PLLA grains followed by unmoulding at room temperature to obtain the microneedles (Han et al. 2009). A more efficient process was studied by Youn et al. (2008) by fabricating silicon moulds using focused ion beam and then pressing the silicon mould in poly-methyl-methacrylate (PMMA) polymer under applied temperatures above the glass transition temperature of PMMA and pressure followed by slow cooling resulted in good reproducibility of replicated structures (Youn et al. 2008). Hot embossing appears only suitable for high temperature stable drugs in a biodegradable polymer vehicle as temperatures of over $100^{\circ} \mathrm{C}$ are required.

As a substantial number of biodegradable microneedles are classed polymers, a supposedly third fabrication technique called investment moulding has been used suitably for hollow non-biodegradable polymers in which a drug solution flows through the hollow part of the microneedles into the skin (Lippmann 2007; Lippmann and Pisano 2006). Melt injection processes in investment moulding are suitable for thermoplastics because in adaptation of micromoulding, very high shear is required to allow for lower viscous melt and low resistant flow but heat generation can cause degradation of the drug formulation (Zhao et al. 2003).

As mentioned earlier, currently there seems to be no lidocaine loaded biodegradable microneedle polymer systems published at present. Table 1 outlines the dissolvable or biodegradable materials as a vehicle for the drug and the method and conditions in manufacturing in-conjunction to significant dissolution or permeation results.

Table 1 


\section{Possible biomaterials for controlled lidocaine release from microneedles}

Lidocaine requires controlled release microneedles that allow for initial fast release into skin but reaches the desired plateau levels in which finite dosage is achieved. Therefore, the microneedles have to dissolve or disintegrate in the tissue fluids of physiological conditions at that site near the laceration before medics can treat the area by cleaning and suturing. Drug molecules directly suspended in a well-mixed polymer microneedle matrix contribute to faster recorded time release than those encapsulated in microparticles followed by suspension in a second matrix vehicle as it is a two stage release mechanism with outer matrix dissolving first. For example, the time of drug release has been reported as $4 \mathrm{~h}$ when calcein was released from PLGA (85/15) obtained commercially in solid state via preprocessed moulded microneedles compared with the same drug encapsulated in NaCMC followed by PLGA in which the result was reported as 4 days (Garland et al. 2011; Park et al. 2006). The polymer and co-polymer monomeric ratios are influential in degradation for drug release. For example, single carbohydrate polymer poly-L-lactic acid (PLLA) with intrinsic viscosity value 2.38 was acquired commercially as a solid and processed into films and the result showed significantly slower degradation by hydrolysis in the release of lidocaine compared with PLGA (80:20) films which controlled released over $60 \%$ of lidocaine in forty days (Loo et al. 2010). PLGA 50:50 microparticles loaded with lidocaine resulted in much faster controlled release of over 50\% in 10 days (Klose et al. 2010). Lidocaine loaded PLGA would be highly suitable for relieving long duration symptoms of skin irritation and discomfort caused by illnesses such as postherpetic neuralgia, previously mentioned for commercially available lidoderm. PLLA's starting monomers, L-lactic acid (LLA), can be derived by carbohydrate fermentation methods with lactic acid bacteria depending on the strain of lactobacillus (Garlotta 2001; Roy et al. 1982). The distinct synthetic step in the production of PLLA is the condensation polymerisation of LLA in which ester linkages between LLA monomers are formed and water is the by product (Mehta et al. 2005; Garlotta 2001). PLGA is synthesized by the mechanism of structural ring opening polymerisation of $D, L$-lactide and glycolide by catalysis from stannous 2-ethyl hexanoate in conjunction with a molecular 
weight- regulating additive, triphenylsilanol with the overall objective of consistent chain length and reduction of side branch chains (Ouyang et al. 2011; Mazarro et al. 2009).

Biodegradation in the context for polymers is the breakdown of a high molecular weight molecule into smaller components of low molecular weight molecules caused by enzymes from microorganisms and/or environmental catalysts (Luckachan and Pillai 2011; Wang et al. 2003). Table 2 provides a summary of biodegradable polymer systems with respect of morphological properties and biodegradation measurements while physiological conditions according to plasma fluid are kept constant. The overall trend from Table 2 shows that the degradation is faster for PLLA blends than PLLA itself. Also, it seems that PLGA 50:50 is much faster degrading than PLGA 75:25.

\section{Table 2}

\section{Tensile properties of biodegradable microneedles}

Dissolvable/biodegradable microneedles require quality testing to determine the maximum direct force required on the base unit before fracturing or crumbling occurs from the tip to the body of the microneedles. Such a test can be done using an axial load testing station which relies on gradually moving the microneedles into a block of metals (e.g. aluminium) until needle breakages are evident (Bariya et al. 2011). A measured section of the metal block contains a pre-determined thickness of skin attached by dual sticky tape and the other section of the block is connected to a compression cell containing microneedles and motorised actuator. The actuator provides a method for constant speed of microneedles insertion into the skin with the output measurement as force (Khanna et al. 2010). A number of components have been used to control tensile strength of dissolving microneedles as shown in Table 3.

Table 3

\section{Conclusions}


Although a number of lidocaine based transdermal products can be found in the market there is a large gap for lidocaine microneedle products, especially biodegradable microneedles. This implies that considerable amount of new research is required at the developmental and pre-clinical setting in order to achieve the desired controlled release of lidocaine into skin and maintain a steady drug concentration for a short duration of time for the purpose of superficial suturing of a cut. A biodegradable lidocaine microneedle system formulated from carboxymethylcellulose demonstrated the increase in pharmacokinetic permeation flux, thus highlighting further interest in research of other biodegradable materials as drug vehicles for lidocaine with the aim of achieving faster permeation kinetics in skin with the general idea of a minimal delayed therapeutic action. Also, the development of lidocaine microneedles may provide a scope for a cheaper product as compared with current EMLA formulations containing lidocaine in which a second local anaesthetic, prilocaine add to the material costs.

The manufacturing of biodegradable microneedles via a casting process with usage of SU-8 or PDMS moulds is economical mainly because these moulds can be re-used numerous times in mass production of biodegradable microneedles. The mechanical penetration strengths are a highly important physical challenge seen in biodegradable microneedles. Not only is a sharp tip of microneedle necessity in cutting through skin but the casted dissolvable material requires adequate resistant to compression forces that mimic finger or thumb pressures. Dissolvable materials with soft solid or brittle physical properties require mucoadhesive co-polymer agents such as PVA or PVP in the mixture to provide for mechanical strength.

\section{References}

Allen LV, Popovich NG, Ansel HC (2005) Ansel's pharmaceutical dosage forms and drug delivery systems, $8^{\text {th }}$ Edn. Lippincott Williams \& Wilkins, pp 131. 
Ameri M, Fan FC, Maa YF (2010) Parathyroid hormone PTH(1-34) formulation that enables uniform coating on a novel transdermal microprojection delivery system. Pharm Res 27: 303-313.

Ami Y, Tachikawa H, Takano N, Miki N (2011) Formation of polymer microneedle arrays using soft lithography. J Micro-Nanolith MEM 10: DOI: 10.1117/1.3553393.

Armani DK, Liu C (2000) Microfabrication technology for polycaprolactone, a biodegradable polymer. J Micromech Microeng 10:80-84.

Arora A, Prausnitz MR, Mitragotri S (2008) Micro-scale devices for transdermal drug delivery. Int J Pharm 364: 227-236.

Banga AK (2009) Microneedle-mediated transdernal delivery: how to contribute to meaningful research to advance this growing field. Transdermal 1: 8-13.

Bariya SH, Gohel MC, Mehta TA, Sharma O.P (2011) Microneedles: an emerging transdermal drug delivery system. J Pharm Pharmacol 64: 11-29.

Bodhale DW, Nisar A, Afzulpurkar N (2010) Structural and microfluidic analysis of hollow side-open polymeric microneedles for transdermal drug delivery application. Microfluid Nanofluid 8: 373-392.

Chen B, Wei J, Tay FEH, Wong YT, Iliescu C (2008) Silicon microneedles array with biodegradable tips for transdermal drug delivery. Microsyst Technol 14: 1015-1019.

Choi NS, Kim CH, Cho KY, Park JK (2002) Morphology and hydrolysis of PCL/PLLA blends compatibilized with $\mathrm{P}(\mathrm{LLA}-\mathrm{co}-\epsilon \mathrm{CL})$ or $\mathrm{P}(\mathrm{LLA}-\mathrm{b}-\epsilon \mathrm{CL})$. J Appl Polym Sci 86:1892-1898.

Chu LY, Choi SO, Prausnitz MR (2010) Fabrication of dissolving polymer microneedles for controlled drug encapsulation and delivery: bubble and pedestal microneedle designs. $\mathrm{J}$ Pharm Sci 99: 4228-4238.

Costa JCS, Neves JS, de Souza MVN, Siqueira RA, Romeiro NC, Boechat N, e Silva PMR, Martins MA (2008) Synthesis and antispasmodic activity of lidocaine derivatives with reduced local anesthetic action. Bioorg Med Chem Lett 18: 1162-1166. 
Dai W, Zhu J, Shangguan A, Lang M (2009) Synthesis, characterization and degradability of the comb-type poly(4-hydroxyl-e-caprolactone-co-e-caprolactone)-g-poly(L-lactide). Eur Polym J 45: 1659-1667.

Danhier F, Ansorena E, Silva JM, Coco R, Le Breton A, Préat V (2012) PLGA-based nanoparticles: An overview of biomedical applications. J Controll Release 161: 505-522.

Dash TK, Konkimalla BVB (2012) Polymeric modification and its implication in drug delivery:

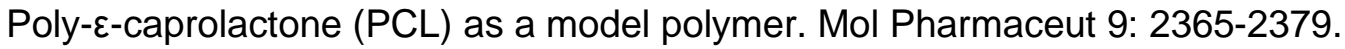

Daugimont L, Baron N, Vandermeulen G, Pavselj N, Miklavcic D, Jullien M-C, Cabodevila G, Mir LM, Préat V (2010) Hollow microneedle arrays for intradermal drug delivery and DNA electroporation. J Membrane Biol 236: 117-125.

Del Camp A, Greiner C (2007) SU-8: A photoresist for high-aspect-ratio and 3D submicron lithography. J Micromech Microeng 17 (6): R81-R95.

Desai MJ, Radhika S, Wang D (2008) Treatment of pain in Dercum's disease with lidoderm ${ }^{\circledR}$ (Lidociane 5\% Patch): A Case Report. Pain Med 9: 1224-1226.

Djabri A, Guy RH, Delgado-Charro MB (2012) Transdermal iontophoresis of ranitidine: An opportunity in paediatric drug therapy. Int J Pharm 435: 27-32.

Donnelly RF, Singh TRR, Tunney MM, Morrow DIJ, McCarron PA, O'Mahony C, Woolfson AD (2009) Microneedle arrays allow lower microbial penetration than hypodermic needles in vitro. Pharm Res 26: 2513-2522.

Donnelly, RF, Singh, TRR, Woolfson, AD (2010). Microneedle-based drug delivery systems: microfabrication, drug delivery and safety. Drug Deliv 17: 187-207.

Donnelly RF, Majithiya R, Singh TRR, Morrow DIJ, Garland MJ, Demir YK, Migalska K, Ryan E, Gillen D, Scott CJ, Woolfson AD (2011) design, optimization and characterisation of polymeric microneedle arrays prepared by a novel laser-based micromoulding technique. Pharm Res 28: 41-57.

Fiala S, Brown MB, Jones SA (2011) Dynamic in-situ eutectic formation for topical drug delivery. J Pharm Pharmacol 63: 1428-1436. 
Fredenberg S, Wahlgren M, Reslow M, Axelsson A (2011) The mechanisms of drug release in poly(lactic-co-glycolic acid)-based drug delivery systems—A review. Int J Pharm 415: $34-52$

Fujita $H$ (1997) A decade of MEMS and its future. IEEE 10th Annual International Workshop on Micro Electro Mechanical Systems: 1-8. DOI: 10.1109/MEMSYS.1997.581729.

Gabor F, Ertl B, Wirth M, Mallinger R (1999) Ketoprofen-poly(D,L-lactic-co-glycolic acid) microspheres: influence of manufacturing parameters and type of polymer on the release characteristics. J Microencapsul 16: 1-12.

Garland MJ, Migalska K, Mahmood TM, Singh TR, Woolfson AD, Donnelly RF (2011) Microneedle arrays as medical devices for enhanced transdermal drug delivery. Expert rev med devic 8 (4): 459-482.

Garland MJ, Migalska K, Tuan-Mahmood TM, Singh TRR, Majithija R, Caffarel-Salvador E, McCarthy HO, Woolfson AD, Donnelly AF (2012) Influence of skin model on in vitro performance of drug-loaded soluble microneedle arrays. Int JPharm 434: 80-89.

Garlotta D (2001) A literature review of poly(lactic acid). J polym environ 9: 63-83.

Gerstel MS, Place VA (1976) Drug delivery device. Alza Corporation.US Patent 3,964,482.

Ginde R, Gupta R (1987) In vitro chemical degradation of poly(glycolic acid) pellets and fibers. J Appl Polym Sci 33: 2411-2429.

Gittard, SD, Chen, B., Xu, H., Ovsianikov, A., Chichkov, BN, Monteiro-Riviere, NA, Narayan, NJ (2012). The effects of geometry on skin penetration and failure of polymer microneedles. J Adhes Sci Technol, DOI:10.1080/01694243.2012.705101

Gupta J, Gill HS, Andrews SN, Prausnitz MR (2011) Kinetics of skin resealing after insertion of microneedles in human subjects. J Control Release 154: 148-155.

Han M, Kim DK, Kang SH, Yoon HR, Kim BY, Lee SS, Kim KD, Lee HG (2009) Improvement in antigen-delivery using fabrication of a grooves-embedded microneedle array. Sensor Actuat BChem 137: 274-280.

Han TY, Park KY, Ahn JY, Kim SW, Jung HJ, Kim BJ (2012) Facial skin barrier function recovery after microneedle transdermal delivery treatment. Dermatol Surg 38: 1816-1822. 
Henry S, McAllister DV, Allen MG, Prausnitz MR (1998) Microfabricated microneedles: A novel approach to transdermal drug delivery. J Pharm Sci 87: 922-925.

Hruby JM (2001) LIGA technologies and applications. M R S Bull [online]. www.mrs.org/publications/bulletin : 337-340.

Jeong WL, Park JH, Prausnitz MR (2008) Dissolving microneedles for transdermal drug delivery. Biomaterials. 29: 2113-2124.

Kaewprapan K, Inprakhon P, Marie E, Durand A (2012) Enzymatically degradable nanoparticles of dextran esters as potential drug delivery systems. Carbohyd Polym 88: 875-881.

Kalluri H, Banga AK (2011) Formation and closure of microchannels in skin following microporation. Pharm Res 28: 82-94.

Kalpan G, Shalini VS, Jonnalagadda S, Kumar N (2007) Fast degradable poly(L-lactide-coe-caprolactone) microspheres for tissue engineering: synthesis, characterization, and degradation behavior. J Polym Sc A1 45: 2755-2764.

Katz NP, Gammaitoni AR, Davis MW, Dworkin RH (2002) lidocaine patch 5\% reduces pain intensity and interference with quality of life in patients with postherpetic neuralgia: an effectiveness trial. Pain Med 3:324-32.

Ke CJ, Lin YJ, Hu YC, Chiang WL, Chen KJ, Yang WC, Liu HL, Fu CC, Sung HW (2012) Multidrug release based on microneedle arrays filled with $\mathrm{pH}$-responsive PLGA microsphere. Biomaterials 33: 5156-5165.

Khanna P, Luongo K, Strom JA, Bhansali S (2010) Sharpening of hollow silicon microneedlesto reduce skin penetration force. J Micromech Microeng 20: 1-8.

Kim BJ, Kim HJ, Jung SM, Sung JK, Lee HH (2009) Fabrication of microneedle using laser written PDMS mold for molecular transport into plant skin. Biochip J 3: 281-286.

Kim MY, Jung B, Park JH (2012b) Hydrogel swelling as a trigger to release biodegradable polymer microneedles in skin. Biomaterials 33: 668-678.

Kim YC, Park JH, Prausnitz MR (2012a) Microneedles for drug and vaccine delivery. Adv Drug Deliver Rev 64: 1547-1568. 
Kissin I (2012) How does the lidocaine patch (5\%) relieve pain? PAIN 153 (6): 1332-1333.

Klose D, Siepmann F, Willart JF, Descamps M, Siepmann J (2010) Drug release from PLGA-based microparticles: Effects of the "microparticle:bulk fluid" ratio. Int J Pharm 383: 123-131.

Kolli CS, Banga AK (2008) Characterization of solid maltose microneedles and their use for transdermal delivery. Pharma Res 25: 104-112.

Kundu J, Mohapatra R, Kundu SC (2011) Silk fibroin/sodium carboxymethylcellulose blended ilms for biotechnological applications. J Biomat Sci-Polym E 22: 519-539.

Kwon SY (2004) In vitro evaluation of transdermal drug delivery by a micro-needle patch. Controlled Release Society $31^{\text {st }}$ Annual Meeting Transactions. TheraJect Inc. no. 115.

Lai PL, Hsu CC, Liu TH, Hong DW, Chen LH, Chen WJ and Chu IM (2012) Mixed micelles from methoxy poly(ethylene glycol)-polylactide and methoxy poly(ethylene glycol)poly(sebacic anhydride) copolymers as drug carriers. React Funct Polym 72: 846-855.

Lee S.J, Lee I.W, Lee Y.M, Lee H.B, Khang G (2004) Macroporous biodegradable natural/synthetic hybrid scaffolds as small intestine submucosa impregnated poly(D,Llactide-co-glycolide) for tissue-engineered bone. J Biomat Sci- Polym E 15: 1003-1017.

Lee JW, Park JH, Prausnitz MR (2008) Dissolving microneedles for transdermal drug delivery. Biomaterials 29: 2113-2124.

Lee S.W, Lee S.S (2008) Shrinkage Ratio of PDMS and its alignment method for the wafer level process. Microsyst Technol 14: 205-208.

Lee JW, Choi SO, Felner El, Prausnitz MR (2011a) Dissolving microneedle patch for transdermal delivery of human growth hormone. SMALL 7 (4): 531-539.

Lee K, Lee CY, Jung H (2011b) Dissolving microneedles for transdermal drug administration prepared by stepwise controlled drawing of maltose. Biomaterials 32: 3134-3140.

Lhernould MS, Delchambre A (2011) Innovative design of hollow polymeric microneedles for transdermal drug delivery. Microsyst Technol 17: 1675-1682,DOI 10.1007/s00542-011$1355-2$ 
Lippmann JM, Geiger EJ, Pisano AP (2007) Polymer investment molding: Method for fabricating hollow, microscale parts. Sensor Actuat A-Phys 134 (1): 2-10.

Lippmann JM, Pisano AP (2006) In-plane, hollow microneedles via polymer investment molding. Proceedings: IEEE Micro Electro Mechanical Systems Workshop: 262-265.

Loo SCJ, Tan ZYS, Chow YS, Lin SLI (2010) Drug release from irradiated PLGA and PLLA multi-layered films. J Pharm Sci 99: 3060-3071.

Lorenz H, Despont M, Fahrni N, La Bianca N, Renand P and Vettiger P (1997) SU-8: a lowcost negative resist for MEMS. J Micromech Microeng 7: 121-124.

Luckachan GE, Pillai CKS (2011) Biodegradable polymers - A review on recent trends and emerging perspective. J Polym Environ 19: 637-676.

Marasso SL, Canavese G, Cocuzza M (2011) Cost efficient master fabrication process on copper substrates. Microelectron Eng 88: 2322-2324.

Martin CJ, Allender CJ, Brain KR, Morrissey A, Birchall JC (2012) Low temperature fabrication of biodegradable sugar glass microneedles for transdermal drug delivery applications. J Control Release 158: 93-101.

Matteucci M, Fanetti M, Casella M, Gramaica F, Gaviolo L, Tormen M, Grenci G, De Angelis F, Di Fabrizio E (2009) Poly vinyl alcohol re-usable masters for microneedle replication. Microelectron Eng 86: 752-756.

Mattioli S, Kenny JM, Armentano I (2012) Plasma surface modification of porous PLLA films: analysis of surface properties and in vitro hydrolytic degradation. J Appl Polym Sci 125 (S2): E239-E247.

Mazarro R, Cabezas LI, De Lucas A, Garcia I, Rodríguez JF (2009) Study of different catalysts and initiators in bulk copolymerization of d,I-lactide and glycolide. J Macromol Sci A 46: 1049-1059.

Mehta R, Kumar V, Bhunia H, Upadhyay SN (2005) Synthesis of Poly(Lactic Acid): A Review. J Macromol Sci Pol R 45: 325-349

Microchem Corp. Material Safety Data Sheet (MSDS). www.microchem.com 
Miyano T, Tobinaga Y, Kanno T, Matsuzaki Y, Takeda H, Wakui M, Hanada K (2005) Sugar micro needles as transdermic drug delivery system. Biomed Microdevices 7: 185-188.

Monheit GD, Campbell RM, Neugent H, Nelson CP, Prather CL, Bachtell N Eng D, Holmdahl L (2009) Reduced pain with use of proprietary hyaluronic acid with lidocaine for correction of nasolabial folds: A patient-blinded, prospective, randomised controlled trial. Dermatol Surg 36: 94-101.

Mundargi RC, Babu VR, Rangaswamy V, Patel P, Aminabhavi TM (2008) Nano/micro technologies for delivering macromolecular therapeutics using poly(D,L-lactide-coglycolide) and its derivatives. J Control Release 125: 193-209.

Natarajan S, Chang-Yen DA, Gale BK (2008) Large-area, high-aspect-ratio SU-8 molds for the fabrication of PDMS microfluidic devices. J Micromech Microeng 18: 1-11.

Olatunji O, Das DB (2010) Painless drug delivery using microneedles. Current technologies to increase the transdermal delivery of drugs (Editor: Joan Escober Chavez). Bentham $\begin{array}{llll}\text { Science } & \text { Publishers } & \text { (available } & \text { online }\end{array}$ http://www.benthamdirect.org/pages/b_getarticlebybook.php). ISBN:978-1-60805-191-5

Olatunji O, Das DB (2011) Drug delivery using Microneedles. Comprehensive Biotechnology (Editor: Zhanfeng Cui). 2nd Edition, MS number 501. MRW, Elsevier, the Boulevard, Langford Lane, Oxford, United Kingdom. ISBN: 13: 978-0-444-53352-4

Ouyang CP, Ma G, Zhao SX, Wang L, Wu LP, Wang Y, Song CX, Zhang ZP (2011) Preparation and characterization of the molecular weight controllable poly(lactide-coglycolide). Polym Bull 67: 793-803.

Orive G, Hernandez RM, Gascon AR, Dominguez-Gil A, Pedraz JL (2003) Drug delivery in biotechnology: present and future. Curr Opin Biotech 14:659-664, DOI 10.1016/j.copbio.2003.10.007

Park JH, Davis S, Yoon YK, Prausnitz MR, Allen MG (2003) Micromachined biodegradable microstructures. In The 16th Annual International Conference on Micro Electro Mechanical Systems, IEEE, Piscataway, NJ :371-374. 
Park JH, Allen MG, Prausnitz MR (2006) Polymer microneedles for controlled release drug delivery. Parm Res 23: 1008-1019.

Park JH, Choi SO, Kamath R, Yoon YK, Allen MG, Prausnitz MR (2007b) Polymer particlebased micromolding to fabricate novel Microstructure. Biomed Microdevices 9: 223-234.

Park JH, Yoon YK, Choi SO, Prausnitz MR, Allen MG (2007a) Tapered conical polymer microneedles fabricated using an integrated lens technique for transdermal drug delivery. IEEE Transactions on Biomedical Engineering 54: 903-913.

Petrisor G, Ion RM, Brachais CH, Couvercelle JP, Chambin O (2012) Designing medical devices based on silicon polymeric material with controlled release of local anesthetics. $\mathrm{J}$ Macromol Sci A 49: 439-444.

Proprietary Lidoderm. Endo pharmaceuticals, Inc., Chadds Ford, CA http://www.lidoderm.com/

Proprietary Prevelle Silk. www.mentorcorp.com

Proprietary Xylocaine. $\quad$ http://www.astrazeneca.co.uk/medicines/products$\underline{\text { az/Product/xylocaine }}$

Qvortrup K, Taveras KM, Trastrup O, Nielsen TE (2011) Chemical synthesis on SU-8. Chem Commun 47: 1309-1311.

Rajabi O, Salari R, Tayyari SF (2011) Study of structure and properties of lidocaine: hydroxpropyl- $\beta$-cyclodextrin inclusion complex. J Pharm Res 4: 1562-1563.

Raphael A.P, Prow TW, Crichton ML, Chen X, Fernando GJP, Kendall MAF (2010) Targeted, needle-free vaccinations in skin using multilayered, densely-packed, dissolving microprojection arrays. SMALL 6 (16): 1785-1793.

Ro AJ, Falotico R, Davé V (2012) Morphological and degradation studies of sirolimuscontaining poly(lactide-co-glycolide) discs. J Biomed Mater Res B 100B (3): 767-777.

Roy TBV, Blanch HW, Wilke CR (1982) Lactic acid production by Lactobacillus delbreuckill in a hollow fiber fermentor. Biotechnol Lett 4: 483-488. 
Ryu WH, Vyakarnam M, Greco RS, Prinz FB, Fasching RJ (2007) Fabrication of multilayered biodegradable drug delivery device based on micro-structuring of PLGA polymers. Biomed Microdevices 9: 845-853.

Safavieh R, Pla Roca M, Qasaimeh MA, Mirzaei M, Juncher D (2010) Straight SU-8 pins. J Micromech Microeng 20: 1-9.

Saliterman SS (2006) Fundamentals of bioMEMS and medical microdevices. Wiley Interscience: 531.

Schreiber S, Ronfani L, Chiaffoni GP, Matarazzo L, Minute M, Panontin E, Poropat F, Germani C, Barbi E (2013) Does EMLA cream application interfere with the success of venepuncture or venous cannulation? A prospective multicentre observational study. Eur J Pediatr 172: 265-268.

Shaikh VR, Dagade DH, Hundivale DG, Patil KJ (2011) Volumetric studies of aqueous solutions of local anesthetical drug compounds [hydrochlorides of procaine (PC $\mathrm{HCl}$ ), lidocaine ( $\mathrm{LC} \mathrm{HCl})$ and tetracaine (TC HCl)] at $298.15 \mathrm{~K}$. J Mol Liq 164: 239-242.

Shakeel M, Pathan Dilnawaz N, Ziyaurrrahman AR, Akber B, Bushra S (2011) Microneedle as a novel drug delivery system: A review. Int Res J Pharmacy 2: 72-77.

Subedi RK, Oh SY, Chun MK, Choi HK (2010) Recent advances in transdermal drug delivery. Arch Pharm Res 33: 339-351.

Sullivan SP, Murthy N, Prausnitz MR (2008) Minimally invasive protein delivery with rapidly dissolving polymer microneedles. Adv Mater 20: 933-938.

Texmac Inc (USA). www.texmac.com

Thaysen AC, Morris AR (1947) The use of hydrofluoric acid in making glass microneedles. J Gen Microbiol 221: 641.

Trautmann A, Heuck F, Mueller C, Ruther P, Paul O (2005) Replication of microneedle arrays using vacuum casting and hot embossing. TRANSDUCERS: 1420-1423.

Tzeng YS, Chen SG (2012) Tumescent technique in digits: a subcutaneous single-injection digital block. The Am J Emerg Med 30: 592-596. 
Ullah I, Baloch MK, Durrani GF (2012) Solubility of lidocaine in ionic, nonionic and zwitterionic surfactants. J Solution Chem 41: 215-222.

Viero Y, He Q, Mazenq L, Ranchon H, Fourniols JY, Bancaud A (2012) Efficient prototyping of large-scale pdms and silicon nanofluidic devices using PDMS-based phase-shift lithography. Microfluid Nanofluid 12 (1-4): 465-473.

Wahit MU, Akos NI, Laftah WA (2012) Influence of natural fibers on the mechanical properties and biodegradation of poly(lactic acid) and poly( $\varepsilon$-caprolactone) composites: A review. Polym Composite 33: 1045-1053.

Walraven JA (2003) Introduction to applications and industries for microelectromechanical systems (MEMS). International Test Conference Proceedings IEEE: 674-680.

Wang MW, Jeng JH (2009) Optimal Molding Parameter Design of PLA Micro Lancet Needles Using the Taguchi Method. Polym Plast Technol 48: 730-735.

Wang XL, Yang KK, Wang YZ (2003) Properties of starch blends with biodegradable polymers. Polym Rev 43: 358-409.

Woodruff MA and Hutmaker DW (2010) The return of a forgotten polymerPolycaprolactone in the 21st century. Prog Polym Sci 35: 1217-1256.

Xiangdong Ye, Liu H, Ding Y, Li H, Lu B (2009) Research on the cast molding process for high quality PDMS molds. Microelectron Eng 86: 310-313.

Yang S, Feng Y, Zhang L, Chen N, Yuan W, Jin T (2012) A scalable fabrication process of polymer microneedles. Int J Nanomed 7: 1415-1422.

You X, Chang JH, Ju BK, Pak JJ (2011) Rapidly dissolving fibroin microneedles for transdermal drug delivery. Mat Sci Eng C 31 (8): 1632-1636.

Youn SW, Okuyama C, Takahasi M, Maeda R (2008) A study on fabrication of silicon mold for polymer hot-embossing using focused ion beam milling. J Mater Process Tech 201: 548-553.

Zhang J, Tan KL, Gong HQ (2001) Characterization of the polymerization of SU-8 photoresist and its applications in micro-electro-mechanical systems (MEMS). Polym Test 20: 693-701. 
Zhang Y, Brown K, Siebenaler K, Determan A, Dohmeier D, Hansen K (2012) Development of lidocaine-coated microneedle product for rapid, safe, and prolonged local analgesic action. Pharm Res 29: 170-177.

Zhao J, Mayes RH, Chen G, Chan PS, Xiong ZJ (2003) Polymer micromould design and micromoulding process. Plast Rubber Compos 32: 240-247. 


\section{List of Tables}

Table 1 Fabricated microneedles according to manufacture, dissolution and permeation of drug

Table 2 Polymer biodegradation and morphology according to physiological plasma fluid conditions

Table 3 Mechanical force properties of microneedle materials and force test results of the microneedle systems 
Table 1 Fabricated microneedles according to manufacture, dissolution and permeation of drug

\begin{tabular}{|c|c|c|c|}
\hline $\begin{array}{l}\text { Microneedle } \\
\text { materials }\end{array}$ & $\begin{array}{l}\text { Methods of } \\
\text { manufacture }\end{array}$ & $\begin{array}{l}\text { Conditions of } \\
\text { manufacture }\end{array}$ & $\begin{array}{l}\text { Results of drug } \\
\text { permeation or } \\
\text { dissolution of vehicle }\end{array}$ \\
\hline $\begin{array}{l}\text { PLA, PLGA (50/50) } \\
\text { and PEG unmixed } \\
\text { initially (Park et al. } \\
\text { 2007b) }\end{array}$ & $\begin{array}{l}\text { Casting with PDMS } \\
\text { (Park et al. 2007b; } \\
\text { Xiangdong et al, 2009) } \\
\text { SU-8 }{ }^{1} \text { photoresist } \\
\text { master (Natarajan et } \\
\text { al. 2008), gold coating } \\
\text { of } 500 \AA \text {. }\end{array}$ & $\begin{array}{l}\text { Ultrasound pulses to } \\
\text { weld polymer } \\
\text { microparticles within } \\
\text { mould to create porous } \\
\text { structure (Park et al. } \\
\text { 2007b). Vacuum } \\
\text { pressure and oven } \\
\text { heating for microneedle } \\
\text { static shaping (Park et } \\
\text { al. 2007b) }\end{array}$ & No publication found \\
\hline $\begin{array}{l}\text { Silk fibroin from } B \text {. } \\
\text { mori c ocoons }{ }^{2} \text { (You } \\
\text { et al. 2011) }\end{array}$ & $\begin{array}{l}\text { Epoxy microneedle } \\
\text { master from X-ray } \\
\text { lithography to produce } \\
\text { female PDMS }{ }^{3} \text { mould } \\
\text { (You et al. 2011). } \\
\text { Molten fibroin drug set } \\
\text { into PDMS and mould } \\
\text { removed (You et al. } \\
\text { 2011) }\end{array}$ & $\begin{array}{l}\text { Oven drying and } \\
\text { vacuum pressure for } \\
\text { shaping and solidifying } \\
\text { microneedles (You et al. } \\
\text { 2011) }\end{array}$ & No publication found. \\
\hline $\begin{array}{l}\text { Poly (methyl vinyl } \\
\text { ether co-maleic acid) } \\
\text { (Garland et al. 2012) }\end{array}$ & $\begin{array}{l}\text { Blulase laser cutting } \\
\text { for fabricated silicone } \\
\text { elastomer moulds } \\
\text { using Aluminium } \\
\text { template (Garland et }\end{array}$ & $\begin{array}{l}40^{\circ} \mathrm{C} \text { heat for curing } \\
\text { mould and centrifugation } \\
\text { at } 3500 \mathrm{~g} \text { for } 15 \mathrm{~min} \text { and } \\
\text { microneedles dried for } \\
24 \mathrm{~h} \text { under ambient }\end{array}$ & $\begin{array}{l}\text { In vitro studies with } \\
\text { Neonatal procine skin } \\
\text { reported } 59 \%, 39 \% \\
\text { and } 23 \% \text { cumulative } \\
\text { release of caffeine, }\end{array}$ \\
\hline
\end{tabular}




\begin{tabular}{|c|c|c|c|}
\hline & al. 2012) & $\begin{array}{l}\text { temperature (Garland et } \\
\text { al. 2012) }\end{array}$ & $\begin{array}{l}\text { lidocaine and } \\
\text { metronidazole } \\
\text { respectively for } \\
\text { combined concoction } \\
\text { microneedles were } \\
\text { tested (Garland et al. } \\
\text { 2012) }\end{array}$ \\
\hline $\begin{array}{l}20 \%(w / w) \text { aqueous } \\
\text { blends of co-polymer } \\
\text { Gantrez® AN-139 } \\
\text { (Donnelly et al. 2011) }\end{array}$ & $\begin{array}{l}\text { Galvanometer } \\
\text { controlled Excimer } \\
\text { laser for variable } \\
\text { height and } \\
\text { interspacing of } \\
\text { microneedle mould } \\
\text { setup (Donnelly et al. } \\
\text { 2011) } \\
\text { Blulase laser cutting } \\
\text { for fabricated silicone } \\
\text { elastomer moulds } \\
\text { using Aluminium } \\
\text { template (Donnelly et } \\
\text { al. 2011) }\end{array}$ & $\begin{array}{l}40^{\circ} \mathrm{C} \text { heat for curing } \\
\text { mould and centrifugation } \\
\text { at } 3500 \mathrm{~g} \text { for } 15 \mathrm{~min} \text { and } \\
\text { microneedles dried for } \\
24 \mathrm{~h} \text { under ambient } \\
\text { temperature (Donnelly } \\
\text { et al. 2011) }\end{array}$ & $\begin{array}{l}83 \% \text { of the drug, } \\
\text { theophylline, contained } \\
\text { in microneedles, } \\
\text { permeated past the } \\
\text { skin compared to 5.5\% } \\
\text { with patch delivery } \\
\text { over a } 24 \text { h period } \\
\text { (Donnelly et al. } 2011 \text { ) } \\
\text { The percentage is out } \\
\text { of total drug loaded. }\end{array}$ \\
\hline $\begin{array}{l}\text { Trehalose/mannitol } \\
(50: 50 \mathrm{w} / \mathrm{w}), \\
\text { trehalose dihydrate/ } \\
\text { sucrose }(75: 25 \mathrm{w} / \mathrm{w}) \text {, } \\
\text { trehalose/sucrose } \\
(75: 25 \mathrm{w} / \mathrm{w}) \text { and } \\
\text { trehalose/sucrose } \\
(50: 50 \mathrm{w} / \mathrm{w}) \text { (Martin }\end{array}$ & $\begin{array}{l}\text { PDMS }^{3} \text { mould created } \\
\text { from wet etched silicon } \\
\text { male master (Martin et } \\
\text { al. 2012) }\end{array}$ & $\begin{array}{l}1 \mathrm{~h} \text { vacuum pressure of } \\
\text { (100 mbar) at room } \\
\text { temperature conditions } \\
\text { followed by } 48 \mathrm{~h} \\
\text { dehydration without } \\
\text { vacuum (Martin et al. } \\
2012 \text { ) }\end{array}$ & $\begin{array}{l}\text { Sugar glass } \\
\text { microneedles } \\
\text { containing } 2 \%(\mathrm{w} / \mathrm{w}) \\
\text { methylene blue } \\
\text { powder showed } \\
\text { complete dissolution } \\
\text { between } 10 \text { to } 20 \text { min } \\
\text { after insertion into full }\end{array}$ \\
\hline
\end{tabular}




\begin{tabular}{|c|c|c|c|}
\hline et al. 2012) & & & $\begin{array}{l}\text { thickness human skin } \\
\text { (Martin et al. 2012) }\end{array}$ \\
\hline $\begin{array}{l}\text { Maltose } \\
\text { monohydrate }(1 \mathrm{~g} / \mathrm{ml}) \\
\text { in deionised water } \\
\text { (Lee et al. } 2011 \mathrm{~b})\end{array}$ & $\begin{array}{l}\text { Stainless steel pillars } \\
\text { and syringe pump to } \\
\text { directly draw molten } \\
\text { maltose into conical } \\
\text { microneedles (Lee et } \\
\text { al. 2011b) }\end{array}$ & $\begin{array}{l}\text { Axial drawing at } 400 \\
\mu \mathrm{m} / \mathrm{s} \text { for } 1 \mathrm{~s} \text { at } 100{ }^{\circ} \mathrm{C} \\
\text { then } 400 \mu \mathrm{m} / \mathrm{s} \text { for } 3 \mathrm{~s} \text { at } \\
96{ }^{\circ} \mathrm{C} \text {, cooling to } 60^{\circ} \mathrm{C} \\
\text { and separation from } \\
\text { attached support pillars } \\
\text { at } 700 \mu \mathrm{m} / \mathrm{s} \text { (Lee et al. } \\
\text { 2011b) }\end{array}$ & $\begin{array}{l}\text { Optical micrography } \\
\text { showed complete } \\
\text { dissolution of maltose } \\
\text { microneedle } \\
\text { containing } \\
\text { sulforhodamine B in } \\
\text { guinea pig skin after } \\
20 \text { min (Lee et al. } \\
2011 b \text { ) }\end{array}$ \\
\hline $\begin{array}{l}\text { Maltose (analytical } \\
\text { grade) in water (Kolli } \\
\text { and Banga 2008) }\end{array}$ & $\begin{array}{l}\text { Pre-fabricated inverse } \\
\text { moulds formed by } \\
\text { etching process } \\
\text { (Texmac Inc) }\end{array}$ & $\begin{array}{l}\text { Direct pouring of molten } \\
\text { maltose at } 95^{\circ} \mathrm{C} \text { into } \\
\text { mould within one min } \\
\text { and gradual cooling to } \\
55^{\circ} \mathrm{C} \text { to prise out the } \\
\text { mould from shaped } \\
\text { microneedles (Kolli and } \\
\text { Banga 2008; Miyano et } \\
\text { al. 2005) }\end{array}$ & $\begin{array}{l}\text { Nicardipine- } \\
\text { hydrochloride loaded } \\
\text { maltose microneedles } \\
\text { recorded a mean flux } \\
\text { of } 7.05 \mu \mathrm{g} / \mathrm{ml} / \mathrm{h} \\
\text { compared with control } \\
\text { value of } 1.72 \mu \mathrm{g} / \mathrm{ml} / \mathrm{h} \\
\text { (Kolli and Banga } 2008 \text { ) }\end{array}$ \\
\hline
\end{tabular}

${ }^{1}$ SU-8 is a high viscosity, negative based photo resist structure for moulding applications.

${ }^{2}$ B. mori cacoons are natural silk cocoon fibrons spun by the silkworm, Bombyx mori.

${ }^{3}$ PDMS is a silicone based inert polymer material, polydimethylsiloxane. 
Table 2 Polymer biodegradation and morphology according to physiological plasma fluid conditions.

\begin{tabular}{|c|c|c|}
\hline Polymer & Morphological properties & $\begin{array}{l}\text { Degradation studies in physiological }{ }^{1} \\
\text { conditions }\end{array}$ \\
\hline Poly-E-caprolactone (PCL) & $\begin{array}{l}\text { Injection moulded matrix, } \\
\text { films and sheets via } \\
\text { temperature settings (Wahit } \\
\text { et al. 2012) }\end{array}$ & $\begin{array}{l}\text { General long term degradation from } \\
\text { weeks to months (Dash and } \\
\text { Konkimalla 2012). In vivo } \\
\text { degradation cannot occur readily } \\
\text { due to unavailability of desired } \\
\text { enzymes and surface erosion } \\
\text { caused by hydrolysis is the primary } \\
\text { mechanism and the main reason for } \\
\text { slow degradation of PCL (Ginde and } \\
\text { Gupta 1987; Woodruff and } \\
\text { Hutmaker 2010) }\end{array}$ \\
\hline PLLA & $\begin{array}{l}200 \text { micron and } 20 \text { micron } \\
\text { films (Mattioli et al. 2012) }\end{array}$ & $\begin{array}{l}5 \% \text { weight loss by hydrolytic } \\
\text { degradation after } 49 \text { days (Mattioli et } \\
\text { al. 2012) }\end{array}$ \\
\hline $\begin{array}{l}\text { Mixed mPEG5000-PSA }{ }^{2} \\
\text { and mPEG2000-PLLA } \\
\text { (Lai et al. 2012) }\end{array}$ & $\begin{array}{l}\text { Spherical micelles with } \\
\text { hydrophobic matrix and } \\
\text { hydrophilic exterior layer (Lai } \\
\text { et al. 2012). }\end{array}$ & $\begin{array}{l}\text { Degradation measured from } \\
\text { calculation percentage release of } \\
\text { curcumin in } \mathrm{PBS}^{4} \text {. Burst release of } \\
\text { curcumin near to } 40 \% \text {. Maximum } \\
75 \% \text { approximate release of } \\
\text { curcumin on day } 15 \text { (Lai et al. 2012). }\end{array}$ \\
\hline $\begin{array}{l}P(L L A-C o-\varepsilon C L)^{5} \text { and } \\
P(L L A-b-\varepsilon C L)^{6} \text { (Choi et al. } \\
\text { 2002). }\end{array}$ & $\begin{array}{l}240 \text { micron thick films (Choi } \\
\text { et al. 2002) }\end{array}$ & $\begin{array}{l}\text { No degradation studies carried out } \\
\text { at physiological conditions so far. }\end{array}$ \\
\hline $\begin{array}{l}\text { P(LLA-co-ECL) (90/10) } \\
\text { (Kalpan et al. 2007) }\end{array}$ & $\begin{array}{l}\text { Smooth surface } \\
\text { Microspheres (Kalpan et al. }\end{array}$ & $\begin{array}{l}60 \% \text { decrease by hydrolytic } \\
\text { degradation in molecular weight }\end{array}$ \\
\hline
\end{tabular}




\begin{tabular}{|c|c|c|}
\hline $\begin{array}{l}\text { PHCL-g-PLLA }{ }^{7} \text { (Dai et al. } \\
\text { 2009) }\end{array}$ & $\begin{array}{l}\text { 2007) } \\
\text { Comb graft polymer films of } \\
110-120 \text { microns (Dai et al. } \\
2009 \text { ) }\end{array}$ & $\begin{array}{l}\text { after } 112 \text { days (Kalpan et al. 2007) } \\
55 \% \text { weight loss after } 70 \text { days (Dai } \\
\text { et al. 2009) }\end{array}$ \\
\hline PLGA & $\begin{array}{l}5600 \text { micron diameter } \\
\text { Sirolimus }{ }^{8} \text { loaded films (Ro } \\
\text { et al. 2012) }\end{array}$ & $\begin{array}{l}\text { 25\% weight loss after } 13 \text { days for } \\
\text { Sirolimus loaded PLGA 50:50 (Ro et } \\
\text { al. 2012). } \\
\text { 22\% mass loss after } 55 \text { days for } \\
\text { Sirolimus loaded PLGA 75/25 (Ro et } \\
\text { al. 2012) }\end{array}$ \\
\hline \multicolumn{3}{|c|}{ Conditions refer to a plasma fluid of $\mathrm{pH} 7$ and temperature of $37^{\circ} \mathrm{C}$. } \\
\hline \multicolumn{3}{|c|}{${ }^{2}$ Methoxy poly(ethylene glycol) (mPEG), 5000 Daltons, Poly(sebacic anhydride) (PSA). } \\
\hline \multicolumn{3}{|c|}{3 Methoxy poly(ethylene glycol) (mPEG), 2000 Daltons. Poly-L-lactide (PLLA). } \\
\hline \multicolumn{3}{|c|}{${ }^{4}$ Phosphate buffer solution, $\mathrm{pH} 7.4$. } \\
\hline \multicolumn{3}{|c|}{${ }^{5} \mathrm{P}($ LLA-b-_CL) is a diblock co-polymer with MW 15200} \\
\hline \multicolumn{3}{|c|}{${ }^{6} \mathrm{P}($ LLA-CO-_CL) is a random polymer with MW 51000} \\
\hline 7 PHCL-g-PLLA poly(4-hydr & I-e-caprolactone-co-e-caprol & one)-g-poly(L-lactide) \\
\hline
\end{tabular}


Table 3 Mechanical force properties of microneedle materials and force test results of the microneedle systems

\begin{tabular}{|c|c|c|}
\hline Microneedle system & $\begin{array}{l}\text { Component with external } \\
\text { force tolerance }\end{array}$ & Results of force tests \\
\hline $\begin{array}{l}\text { Polylactic acid (PLA) (Wang } \\
\text { and Jeng. 2009) }\end{array}$ & $\begin{array}{l}\text { Injection grade PLA (Wang } \\
\text { and Jeng 2009) }\end{array}$ & $\begin{array}{l}73.11 \% \text { impact on structural due } \\
\text { to melt temperature variable } \\
\text { (Wang and Jeng } 2009 \text { ) }\end{array}$ \\
\hline $\begin{array}{l}\text { NIPAAm }{ }^{1} \text { based hydrogel } \\
\text { loaded into Poly lactic-co- } \\
\text { glycolic acid (PLGA) (Kim et al. } \\
2012 \text { ) }\end{array}$ & $\begin{array}{l}\text { Mainly PLGA (Kim et al. } \\
\text { 2012) }\end{array}$ & $\begin{array}{l}\text { PLGA microneedles with } 18 \% \mathrm{v} / \mathrm{v} \\
\text { hydrogel deformed less than the } \\
31 \% \mathrm{v} / \mathrm{v} \text { hydrogel ones (Kim et al. } \\
2012 \text { ) }\end{array}$ \\
\hline $\begin{array}{l}\text { Sugar glass disaccharide } \\
\text { mixture of two sugar } \\
\text { components except xylitol } \\
\text { (Martin et al. 2012) }\end{array}$ & $\begin{array}{l}\text { Similar molecular weight of } \\
\text { two specific disaccharides } \\
\text { that formed solid sugar } \\
\text { (Martin et al. 2012) }\end{array}$ & $\begin{array}{l}\text { Qualitative skin penetration tests } \\
\text { showed most microneedles } \\
\text { penetrated skin and complete } \\
\text { dissolution in skin after } 10 \text { min } \\
\text { (Martin et al. 2012) }\end{array}$ \\
\hline $\begin{array}{l}\text { Polyvinylpyrrolidone (PVP), } \\
\text { PLGA, PVA (Ke et al. 2012) }\end{array}$ & $\begin{array}{l}\text { PVP (10000 MW) (Ke et al. } \\
\text { 2012) }\end{array}$ & $\begin{array}{l}\text { Microneedles fabricated with } 600 \\
\mathrm{mg} / \mathrm{ml} \text { and } 1000 \mathrm{mg} / \mathrm{ml} \text { PVP were } \\
\text { robust as confirmed from SEM } \\
\text { images after insertion. The latter } \\
\text { PVP concentration showed no } \\
\text { geometric change (Ke et al. 2012) }\end{array}$ \\
\hline $\begin{array}{l}\text { PVP, PVP-MAA }{ }^{2} \text { poly(vinyl } \\
\text { pyrrolidone-co-methacrylic } \\
\text { acid (Sullivan et al. 2008) }\end{array}$ & $\begin{array}{l}\text { PVP (8970 MW), MAA } \\
\text { (Sullivan et al. 2008) }\end{array}$ & $\begin{array}{l}\text { Displacement force tests proved } \\
\text { that } 1 \% \text { MAA in PVP-MAA } \\
\text { contributed to nearly double the } \\
\text { strength of PVP alone (Sullivan et } \\
\text { al. 2008) }\end{array}$ \\
\hline $\begin{array}{l}\text { PVA/PVP blends (Chu et al. } \\
\text { 2010) }\end{array}$ & $\begin{array}{l}\text { PVA (2000 MW) (Chu et al. } \\
\text { 2010) }\end{array}$ & $\begin{array}{l}\text { Qualitative skin penetration tests } \\
\text { showed } 80 \% \text { of microneedle tips }\end{array}$ \\
\hline
\end{tabular}




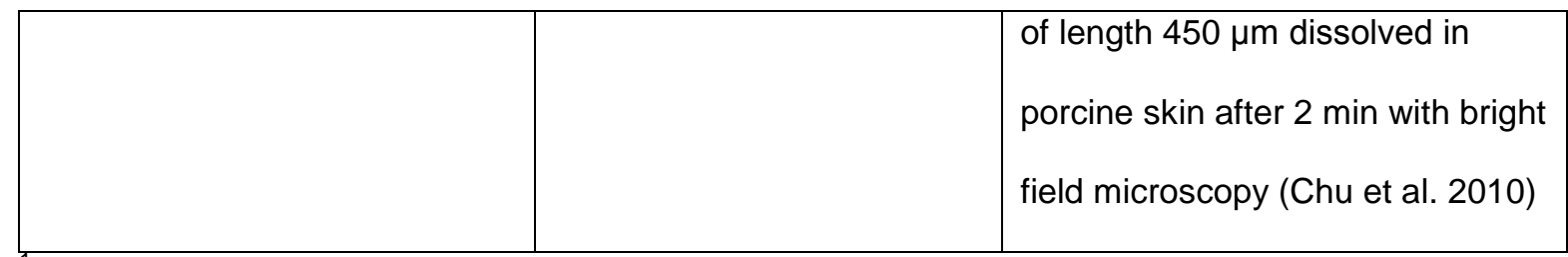

N-isopropylacrylamide (NIPAAm)

${ }^{2}$ Poly (vinyl pyrrolidone-co-methacrylic) acid 


\section{List of Figures}

Fig. $1 \mathrm{a}$ The chemical structure of hydrophobic form of local anaesthetic lidocaine (Costa et al. 2008)

Fig. 1 b The hydrophilic form of lidocaine known as lidocaine hydrochloride (Shaikh et al. 2011).

Fig. 2 a Schematic outline of a diffusing biodegradable microneedle after skin insertion.

Fig. 2 b Pyramidal sodium carboxymethyl cellulose microneedles containing sulforhodamine B (Jeong et al. 2008)

Fig. 2 c Scanning electron microscope image of conical PLGA microneedles (Park et al. 2007)

Fig. 3 a Stages in micromoulding of biodegradable PVP/PVA microneedles (Chu et al. 2010)

Fig. 3 b Stages in micromoulding of biodegradable PLGA microneedles (Park et al. 2003) 


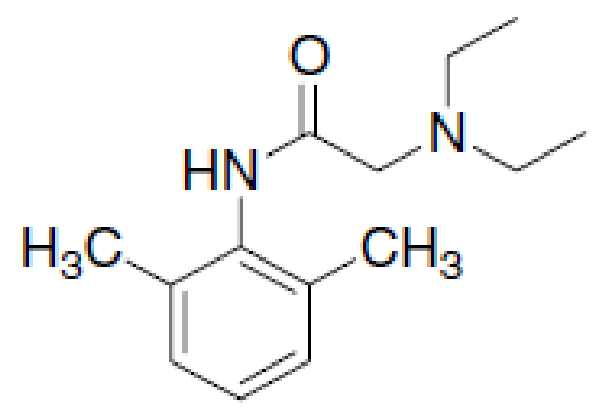

Fig. $1 \mathrm{a}$ 


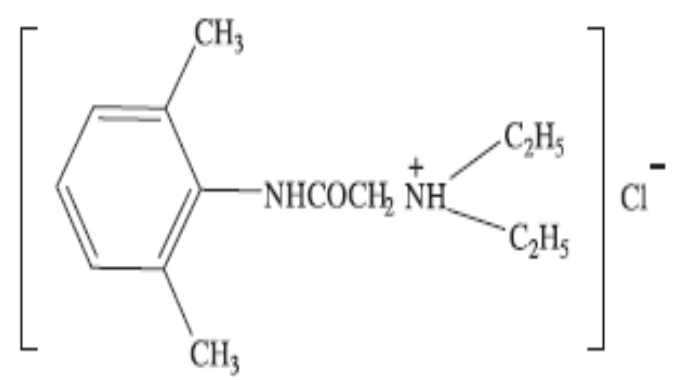

Fig. 1 b 


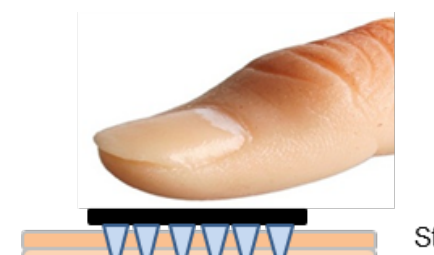

Stratum Corneum

Viable Epidermis

Dermis

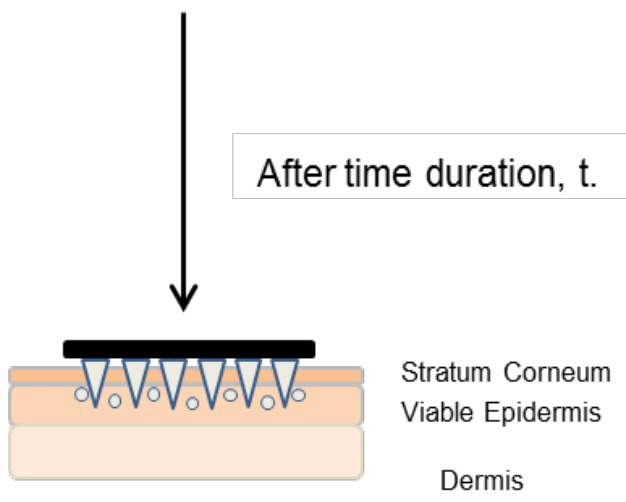

Fig. $2 \mathrm{a}$ 


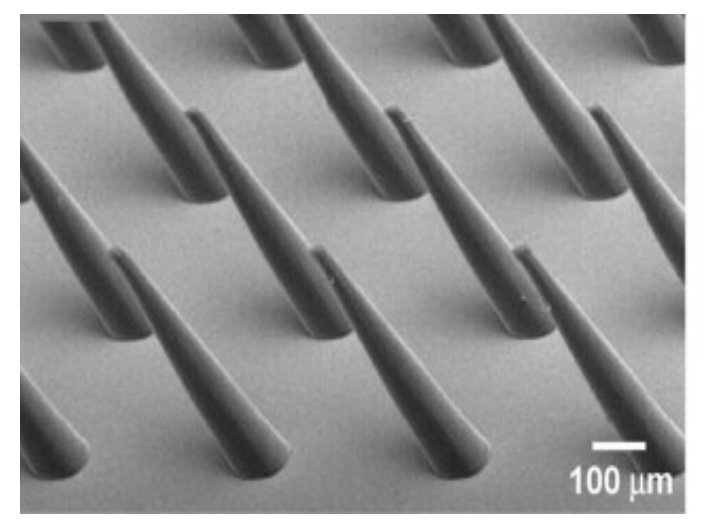

Fig. 2 b 


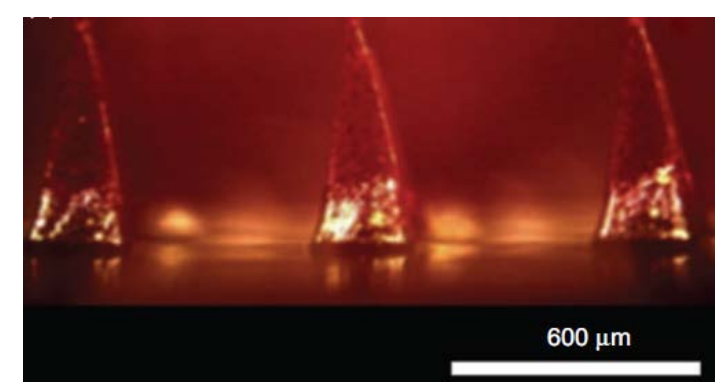

Fig. $2 \mathrm{C}$ 

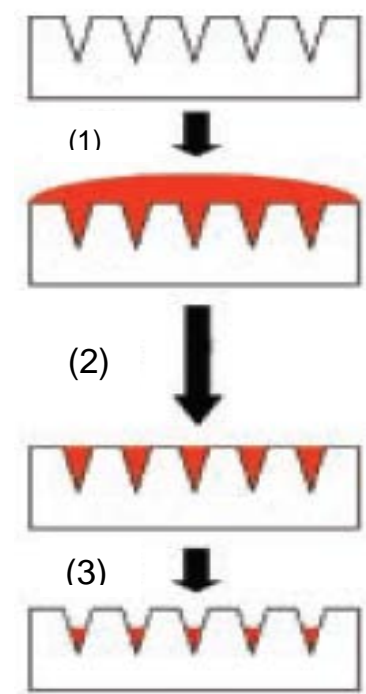

(4)

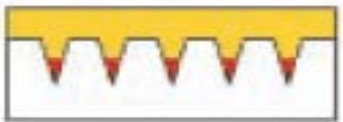

Polymer

(5)

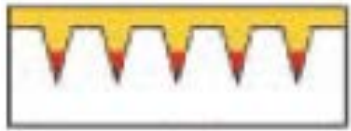

(6)

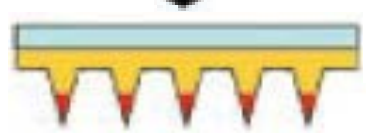

Adhesive

backing

Fig. 3 a 


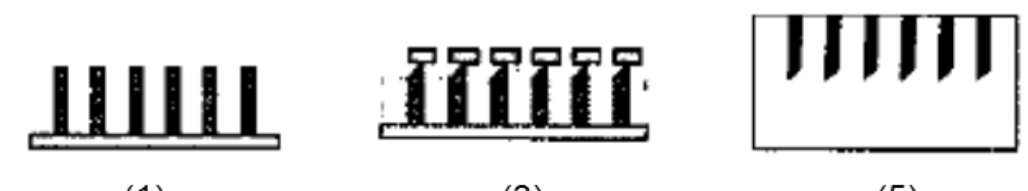

(1)

(3)

(5)

\section{IIIIII}

(2)

\section{IIIIIII}

(4)


(6)

Fig. 3 b 